\title{
An ex situ and in vitro approach to delineate pennate diatom species with bioindicator potentials in a well mixed tropical estuarine ecosystem
}

\author{
Abhishek Mukherjee, Subhajit Das, Sabyasachi Chakraborty and \\ Tarun Kumar De*
}

Department of Marine Science, Calcutta University; 35, B.C. Road, Kolkata-700 019.

*Email: tarunde@yahoo.co.in.

\begin{abstract}
An experiment was performed on selected pennate diatom species collected from the well mixed waters of the Hooghly Estuary with the aim of distinguishing the ones with qualities to be employed as monitors of their ecosystem. The Hooghly Estuary is enriched with domestic, sewage and agricultural effluents and coastal upwelling along with tide-mediated advective circulation from the mangrove forests ensure concomitant nutrient pool replenishment in this ecoregion. There have been several attempts to establish certain centric diatom species as bioindicators in various parts of the world owing to their better responsiveness to sudden shifts in stoichiometry but hardly any with pennate diatoms. Pennate diatoms are typical benthic mat formers in the intertidal regions, on submerged surfaces and thus bear greater feasibility to be employed as accurate pointers to long term deviations in their respective ecosystems, in spite of the greater sensitivity of the centric diatoms. The study was carried out in laboratory controlled environment to minimize the interference from other extrinsic factors compromising the outcome and also due to the fact that such studies to be performed in natural conditions require a decent financial support and time to conclusively arrive upon the objectives. From the present endeavour it was inferred that Nitzschia sigmoidea, Pleurosigma angulatum and Ulnaria oxyrhyncus (formerly Synedra ulna var. oxyrhyncus) stood a good chance of being recruited as bioindicators to eutrophic well mixed estuaries, similar to the one they had been sampled from.
\end{abstract}

Keywords: Pennate; Diatoms; Hooghly Estuary; Well mixed estuary; Bioindicators.

\section{Introduction}

One of the most dominant life forms in the aquatic realm of the earth is the phytoplankton and diatoms are the most populous phytoplankton communities belonging to the Family Bacillariophyceae. Diatoms vary greatly in their shapes and sizes and as a result have a varied surface
Received

November 11, 2016

Accepted

December 27, 2016

Released

December 31, 2016

Open Acess

Full Text Article

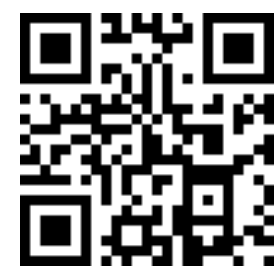

ORCID

(ㄱ) 0000-0001-6690-5193

Abhishek Mukherjee

() 0000-0002-7824-6962 Subhajit Das

(ㄱ) 0000-0001-9691-4314 Sabyasachi Chakraborty () 0000-0003-2733-7116

Tarun Kumar De area to volume ratio, enabling them to exploit and utilize available growth sustaining resources better than their co-habitators.

Due to their ephemeral life span, phytoplankton can respond quickly to subtle changes in their ambient environment and such responses in phytoplankton may serve as beacons of 
significant physical, chemical or biological changes happening in the water column (Hotzel and Croome, 1999). Timmermans (2001) studied the growth rates of large and small Southern Ocean diatoms in relation to the availability of micronutrients $\left(\mathrm{Fe}^{+}\right)$in natural seawater. Studies such as these are available aplenty but exactly the species wise phytoplankton (diatom) indicators of the nutrient status have not been studied in details in the Hooghly Estuarine Region of the Bay of Bengal.

Microalgae can grow rapidly in natural waters that are extremely low in essential macro and micro nutrients. Yet, their nutrient uptake systems exhibit only mediocre nutrient affinities, the saturation constants being often 10-1,000 times the estimated ambient concentrations (Morel, 1987). In oligotrophic temperate and tropical waters, nutrient availability is generally considered to be the main factor affecting the phytoplankton growth rates (Dugdale and Goering, 1967; DiTullilo et al., 1993), biomass (Dugdale et al., 1992; Graziano et al., 1996), which among the available nutrient pool is most critical, is debatable (Smith and Atkinson, 1984). In general nitrogen species (mainly dissolved nitrate) and phosphorus species (especially dissolved orthophosphate) are considered to be the limiting nutrients for growth and primary production by phytoplankton. Since diatoms constitute the dominant fraction of the phytoplankton, silicates are considered one of the significant nutrient parameters during the monitoring of an aquatic ecosystem. Ecosystems with ratios of dissolved inorganic nitrogen to phosphorus less than the average phytoplankton intracellular ratio $(\mathrm{N}$ : $\mathrm{P}=$ 16:1) are generally considered to be $\mathrm{N}$ limited, whereas those with $\mathrm{N}$ : $\mathrm{P}>16: 1$ would be P limited (Redfield et al., 1963; Hecky and Kilham, 1988). Recent studies have shown that macronutrients $(\mathrm{N}, \mathrm{P}$ and $\mathrm{Si}$ ) and trace metals such as $\mathrm{Fe}, \mathrm{Mg}$, and Mn etc. may co-limit algal growth and species composition (Martin et al., 1994; Price et al., 1994). Diatoms owing to their most varied morphometry as well as their underlying physiological patterns to respond to the environmental perturbations make them ideal subjects to study the effects of environmental changes with. Due to their precise reflection of their ambience, certain diatom species can be established as tools to regularly monitor the health of a dynamic aquatic ecosystem.

Monitoring the response of diatom species to a specific shift in the nutrient column might be very tedious and inherently erroneous procedure since the in situ demarcation of a particular ecological manifestation and assigning it to a certain parameter is quite an impossible task since they are always several intervening agents involved and each contribute to the ultimate form or distribution patterns.

The objectives of the study are to delineate some key diatom species with potentials to serve as bio-indicators of estuarine ecosystems and also to compare the growth rate of such species on various synthetic culture media with equally assorted ingredients (macro and micro nutrients, trace metals, vitamins etc.) to get a better idea on the sensitivity of those species to the precise concentrations of certain nutrients (since every culture media has their unique stoichiometry).

Study, such as the present one, is truly important from ecological perspective since establishment of some diatoms as biomonitors to a particular eco-region will not only render monitoring the health of that region easier and accurate in a costeffective manner but also may provide the specific source of feed in aquaculture industries that can grow those phytoplankton with the application of certain nutrients on their ambient media to boost the growth and in turn enrich the industrially cultured species at a cheaper and in a natural manner.

\section{Materials and methods}

Sunderban $\left(21^{\circ} 31^{\prime} \mathrm{E}\right.$ and $22^{\circ} 30^{\prime} \mathrm{N}$; $88^{\circ} 10^{\prime} \mathrm{E}$ and $89^{\circ} 51^{\prime} \mathrm{E}$ ) which means 'beautiful forest' is the largest uninterrupted delta patch in the GangaBrahmaputra Estuary. The total land area today is $4,143 \mathrm{~km}^{2}$ (1,600 sq mi), including exposed sandbars with a total area of 42 $\mathrm{km}^{2}$ (16 sq mi); the remaining water area of 
$1,874 \mathrm{~km}^{2}$ (724 sq mi) encompasses rivers, small streams and canals. Rivers in the Sundarbans are confluence zones of salt water and freshwater. Thus, it is a region of transition between the freshwater of the rivers originating from the Ganges and the saline water of the Bay of Bengal.

Sunderban has a shoreline of 130 $\mathrm{km}$ of total $180 \mathrm{~km}$ coast length of West Bengal. Considering the enormous ecological importance of this region, UNESCO designated it as a World Heritage Site in 1987 (UNESCO, 1999). The Sunderban Biosphere Reserve occupies an area of about 2,585 $\mathrm{km}^{2}$ of which $1330 \mathrm{~km}^{2}$ is in the relatively undisturbed core area and around 1,255 $\mathrm{km}^{2}$ considered as the buffer zone.

General characteristic of the ecosystem is its mangrove vegetation although much of it has dwindled due to unabashed human encroachment. The Sunderban has a physiologically dry soil with high amounts of salt. The edaphic characteristics of the region can be silty, sandy or clayey. Sandy sediment layers are generally encountered near the beach tidal flats extending inwards with the aid of sand dunes and tidal creeks. These are coarser and porous and are not suitable foe accumulation of organic carbon which ultimately forms the fertile surface layer. That is the characteristic of forest or mudflat sediments with visibly higher diversity of flora and fauna. Although the marine influence brought about by the high tides render the surface layers to be alkaline $(\mathrm{pH}>8)$, predominantly it varies from being acidic to neutral ( $\mathrm{pH}$ 5-7.3). The subsurface layers are almost always acidic due to the actions of the anaerobic bacteria and accumulation of litter which ultimately get converted into humic and tannic acid. Another very intriguing feature of the mangrove ecosystem and the beach is the presence of varying degree of bioturbation that greatly affects the physicochemical nature of this ecosystem, mostly in an ameliorative manner but at times also detrimental.

Sunderban area observes three distinct seasons viz. premonsoon (MarchJune), monsoon (July-October) and postmonsoon (November-February). Annual average rainfall ranges from 1,900$2,100 \mathrm{~mm}$. The average maximum and minimum wind velocities range from 16.7$20 \mathrm{Km} \mathrm{h}^{-1}$ (April-June) to 10.7-11.8 $\mathrm{km} \mathrm{h}^{-1}$ during months of December to February, respectively. Sunderban is a tide dominated area where tides are characteristically semidiurnal with slight diurnal inequality. The flood and ebb currents fluctuate with seasons. Higher discharge values were observed during monsoon with an average $(3.0 \pm 1.0) \times 10^{3} \mathrm{~m}^{3} \mathrm{~s}^{-1}$ and maximum of the order of $4,000 \mathrm{~m}^{3} \mathrm{~s}^{-1}$ during freshet (September). Considerably lower discharge values were recorded during premonsoon with an average $(1.0 \pm 0.08) \times 10^{3} \mathrm{~m}^{3} \mathrm{~s}^{-1}$ and minimum of the order of $900 \mathrm{~m}^{3} \mathrm{~s}^{-1}$ in May. In the lower Gangetic West Bengal, usually heavy precipitation occurred during rainy season (June-October) resulting in considerable surface runoff from the catchment areas of Bhagirathi-Hoogly and its tributaries (Mukhopadhyay et al., 2006).

Three sampling stations were selected based on their physiochemical parameters mainly focusing on lower stretch of Hoogly Estuary along with surrounding anthropogenically disturbed marine and coastal ecosystems beginning with greater freshwater influenced ecosystems near estuary head to gradually brackish water regions at the tide dominated estuary mouth. The selection of stations (Figure 1) was based on the pretext of observing the responses of the biotic communities which are constantly influenced by the ever changing stoichiometry of the ambient media. The following is a short description of the sampling stations:

\section{Kachuberia} (21 52.72' N; $\mathbf{8 8}^{\circ} \mathbf{8 . 1 5}$ ' E) - The first station selected is a point of entry on Sagar Islands and is around $32 \mathrm{~km}$ from Gangasagar, affected by freshwater, high tide as well as intense human activities.

Chemaguri $\left(21^{\circ} 38^{\prime} \mathrm{N}\right.$; $\left.8^{\circ}{ }^{\circ} 08^{\prime} \mathrm{E}\right)$ - It is a sub location under Rudranagar Township in South 24 Parganas, West Bengal and characterized by stunted 
mangrove vegetation and high nutrient regeneration during high tides.

\section{Gangasagar $\quad\left(21^{\circ} 80^{\prime} \quad \mathrm{N}\right.$;}

$\mathbf{8 8}^{\circ} \mathbf{1 0}$ ' E) - The Sagar Island is around 100 $\mathrm{km}$ South of Kolkata and Gangasagar is situated at the extreme south of this island. It has one of the highest instances of eutrophication among all the sampling sites due to the ever-increasing stress from urbanization and non-existent sewage treatments as well as from the World famous Sagar Mela pilgrimage along with year-round religious rituals.

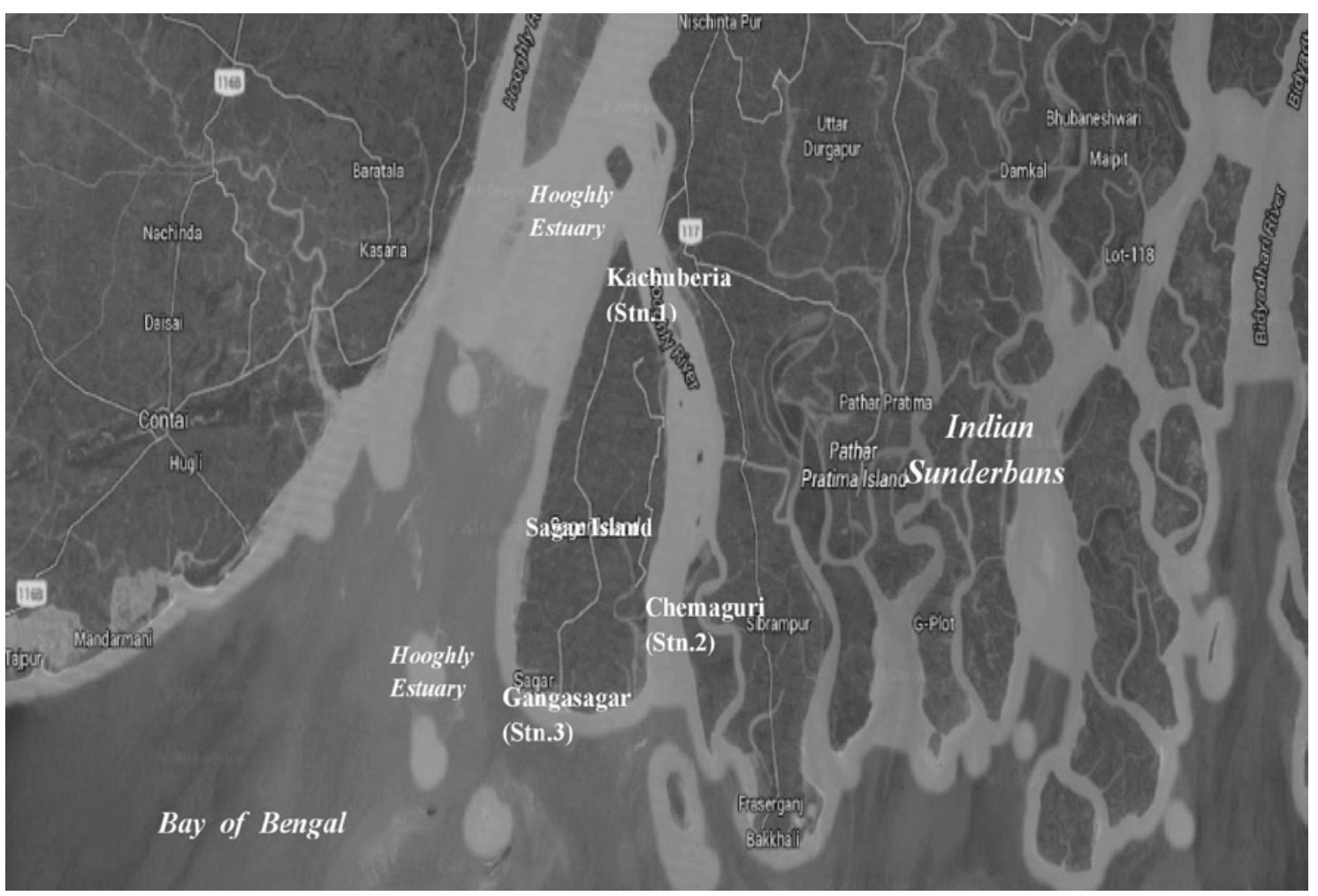

Figure 1. The map is depicting the stations selected as the sites of collection during the field trip. The sites were chosen owing to their varied physico-chemical and biotic nature viz. Kachuberia with relatively greater influence from freshwater; Chemaguri serving as ideal brackish water regimes, with Gangasagar having an almost marine facade (Mukherjee et al., 2015b).

\section{Collection and monitoring}

The sampling at all three selected site was performed only for the month of February'2016 as it is generally considered to be the month of the spring bloom in the region and the chances of collecting various species is best during this period.

Various background parameters were monitored and recorded during the course of the study tenure to understand the scenario and the constraints which affect the phytoplankton population density in time and space. Among the chief physical parameters were air (aT) and surface water temperature (wT), wind speed (WS), relative humidity $(\mathrm{RH})$, precipitation etc. Water and air temperature were recorded using a thermometer calibrated in degrees Celsius. Prevailing wind speed over the sampling sites was recorded using an anemometer. Relative humidity of the days of collection and the seasonal precipitation was monitored with the help of the South 24 Parganas Meteorological Department. The $\mathrm{pH}$ of the water samples was recorded with the help of a digital $\mathrm{pH}$ meter in situ to maintain accuracy since it is one of the most important variables controlling the phytoplankton population. 
Water samples were collected using the Niskin water sampler and stored in pre acid cleaned TARSONS polythene containers. The samples were collected in triplicates in accordance with the general principle of ecological sampling so that the tests and experiments performed with them can be replicated as and when required to ensure the accuracy and the feasibility of the results obtained and natural processes explained based on them. The water samples collected for the purpose of estimation of nutrient contents were transferred to polystyrene casings under cold condition and transported back to the laboratory as soon as possible and stored in refrigerator at $4{ }^{\circ} \mathrm{C}$.

Phytoplankton samplings were performed using the phytoplankton net made of bolting silk (no. 30) with a mesh size of $20 \mu \mathrm{m}$. The mesh size was solely intended for the collection of the microphytoplakton and not the nanoplanktons because in a highly sediment laden environment very small mesh size would render sampling quite difficult due to the silt clogging. The sampling was always performed in regions of relatively lower sediment resuspension and churning (though it is quite difficult to maintain in a well mixed estuary), in case of rivers and creeks it was performed on the mid channel and in case of bay mouths, the sampling was performed on the offshore waters. The chief gear used for the entire period of the study was country boats (apart for the monsoon months when navigation was strenuous by country boats, motorized vessels were in use), since the use of the large motorised vessels would have scattered and stirred the phytoplankton patches (though it is very much so in well mixed estuary). The phytoplankton net was always deployed on the starboard side at the bow of the boat because had the net been deployed at the port side of the boat, it would have made the collection almost impossible due to the propeller wash and stirring of the phytoplankton patches in the wake water.

The net was dragged alongside the vessel for a period of about half an hour and then the net concentrates were transferred to
25 mL TARSONS containers for qualitative analytical purposes. The fixative used for short term storage of the phytoplankton samples was $4 \%$ buffered formalin [100 mL

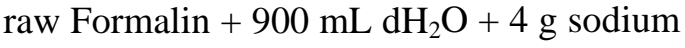
dihydrogen phosphate, monohydrate $\left(\mathrm{NaH}_{2} \mathrm{PO}_{4} \cdot \mathrm{H}_{2} \mathrm{O}\right)+6.5 \mathrm{~g}$ Disodium hydrogen phosphate, anhydrous $\left.\left(\mathrm{Na}_{2} \mathrm{HPO}_{4}\right)\right]$.

For the quantitative analysis, the phytoplankton samples (directly collected by dipping in the water) were collected in $1 \mathrm{~L}$ TARSONS container in triplicate and was preserved with acidic Lugol's iodine and kept undisturbed to accomplish sedimentation. The Lugol's iodine was added to the water sample at a volume which tinted the water and partly buffered formalin was also added since few diatoms species tend to lose their cellular appendages or projection if preserved with Lugol's iodine only. For long term storage of phytoplankton samples, the newly modified combined preservative concentration $[2 \%$ Formalin $+2.5 \%$ acidic Lugol's iodine] (Mukherjee et al., 2014) was employed so that various ecological measurement can be performed on them without compromising on their natural dimensions and introductions of any artefacts - some of the changes induced at times by the preservatives themselves.

The water samples collected were used for analyses of various chemical and biological variables. The chief chemical estimations performed were of the inorganic macronutrient contents, $\mathrm{pH}$, dissolved oxygen, salinity etc. The prime biological parameters investigated were cell density, chlorophyll content, primary productivity, biomass and biovolume etc. The analyses were performed using standard literatures (Strickland and Parsons, 1972; Grasshoff et al., 1983).

The primary equipments used for the detection purposes were Olympus brightfield microscope, Nikon phase contrast and Magnus inverted microscopes. For quantification purpose, the acidic Lugol's iodine preserved phytoplankton samples were kept undisturbed for a period of one week and then the supernatant was gently siphoned off, keeping only the 
settled silt and phytoplankton cells. A small piece of phytoplankton net similar in mesh size with the one used for sampling was used to prevent escape of cells while decanting the water. With the help of glass capillary droppers $1 \mathrm{~mL}$ of sample was used each time for counting the number of cells. The enumeration was performed with the help of Sedgwick rafter counter chamber. The identification of the phytoplankton species was accomplished with help of validly published renowned literatures (AlKandari et al., 2009; Hasle and Syvertsen, 1997; Desikachary, 1986-1989).

Several pennate species were collected during the sampling period and all were inoculated to synthetic culture media. Only three viz. Nitzschia sigmoidea (Nitzsch) W. Smith, 1853, Pleurosigma angulatum (J. T. Quekett) W. Smith, 1852 and Ulnaria oxyrhyncus (Kützing) $\mathrm{M}$. Aboal in Aboal, A. Cobelas, Cambra \& Ector 2003 (formerly Synedra ulna var. oxyrhyncus (Kützing) O’Meara, 1875) responded quite readily and hence were selected for the present study.

\section{Culture media specifications}

Along with the detection, identification and measurements of the phytoplankton cells, the present thesis comprises a large portion on the laboratory culture of the diatoms for performing various experiments relevant to the objectives of the thesis. In addition to the usage of seawater for culture purposes, an artificial culture media was also employed to observe specific responses to particular water quality variables such as nutrients etc. The media used for this purpose is known as the diatom artificial media or DAM which is the most widely used culture media for diatoms in the United States. The media had been developed by the ProvasoliGuillard Centre for Culture of Marine Phytoplanktons (CCMP) and is a modification over the widely used Guillard f/2 media (Gagneux-Moreaux et al., 2007). The media specifications, although available on the internet, is depicted in the Table 1 for the convenience of the reader. The diatom artificial culture media or DAM (for the rest of the paper this abbreviation will be in use) was stored in $2 \mathrm{~L}$ Erlenmeyer flasks. During the preparation of the media, the nutrient solutions were stored at $6{ }^{\circ} \mathrm{C}$. At the time of preparing the trace metal solution, EDTA was added prior to the application of $\mathrm{FeCl}_{3}$ in order to prevent the precipitation of ferrous oxide. The $\mathrm{pH}$ of the media was adjusted to 7.8 using $1 \mathrm{M} \mathrm{HCl}$.

The culture media was used as enriched seawater and filtered water from the estuary was used along with its enrichments where the final concentrations were $1.89 \mu \mathrm{mol} / \mathrm{L}$ of $\mathrm{PO}_{4}-\mathrm{P}, 75.58 \mu \mathrm{mol} / \mathrm{L}$ of $\mathrm{Si}$ and $17.09 \mu \mathrm{mol} / \mathrm{L}$ of $\mathrm{NO}_{3}-\mathrm{N}$ which more or less reflect the average nutrient load of the Hooghly Estuarine waters all year round.

\section{Inoculation and sub-culturing (Micromanipulation technique)}

The phytoplankton aliquot (about $10 \mathrm{~mL}$ ) was inoculated into the freshly prepared diatom artificial culture media or DAM in five separate Erlenmeyer flasks of $250 \mathrm{~mL}$ volume and was incubated for 5 days. Intermittent checking for any sign of growth was performed using sterilized micropipettes ensuring the absolute contamination free environment possible.

When the diatoms grown in the artificial culture entered the stationary phase of their growth (after the exponential growth ceased), the cells were inoculated in freshly prepared media with varied specifications. The specifications included DAM with 3 times more nitrate and phosphate, DAM with halved nitrate and phosphate amounts along with doubled silicate and a DAM completely devoid of any silicate. The specifications were largely based upon the extent of nutrient fluctuation in the region from where the samples were originally collected. Sub-culturing was generally performed on the 8th day of the inoculation when on average the cultures were in the stationary phase of the growth.

The sub-culturing of the diatom cells were performed by employing the micromanipulation technique. With a fine flame from a Bunsen burner, heat was drawn out (holding at both ends) in the capillary tube to form two micropipettes. 
The narrow end should was about twice the diameter of the cell to be micromanipulated.

A. Double distilled water was heated to simmering point on hot plate. This was used for sterilizing the micropipette between each transfer.

B. Few drops of sterile medium were placed onto $1.5 \%$ agar plates with a sterile Pasteur pipette. Alternatively three drops were placed on a surface cleansed glass slide (method followed during the transfer of phytoplankton cells during the experiments related to the present report).

C. With silicone tubing attached to micropipette, a small amount of hot distilled water was gently sucked up without letting it come in contact with the palate at all and blown out. This processed helped sterilize the improvised micropipette.

D. The next step was to detect the algal cell to be isolated in drop of enrichment sample. This was achieved by sucking up the cell while it was under observation.

E. The cell was transferred to a drop of sterile medium on agar plate or glass slide.

F. The micropipette was again sterilized following the same method.

G. The above described process was repeated to "wash" the cell. The more times a cell is washed the less likely is bacterial contamination. However, the risk of cell damage increases with the number of times a cell is handled. The optimum number of washes depends on the type of algae.

H. The washed cell was transferred to a diluted medium in a tissue culture plate, Petri dish or culture tube.
I. After completion of the subculturing steps, the culture vessels were kept under low light at appropriate constant temperature. Check microscopically for growth or wait until macroscopic growth can be detected (1 to 3 weeks after transfer).

\section{experiment \\ Laboratory set up for the entire}

The culture flasks (Erlenmeyer flasks) were kept in a custom-built airconditioned incubator with automatic aeration mechanism along with exhaust panels for sucking and venting out warm air. The $250 \mathrm{~mL}$ flasks containing $150 \mathrm{~mL}$ of media were constantly gyrated on a metal spring grid-lined shaker top to prevent settling down of the phytoplankton cells. The area of the incubator was $12.5 \mathrm{ft}^{2}$ $\left(\sim 1.16 \mathrm{~m}^{2}\right)$ and the racks were transparent so that there would be no blockage of light. One 'Osram White' $40 \mathrm{~W}$-fluorescent lamp was installed and used as the light source. It had luminous efficacy of $60 \mathrm{~lm} / \mathrm{w}$ (lumen per Watt), which provided $\sim 2,067$ lux of light energy. The culture flasks were kept at distances of $15 \mathrm{~cm}$ from the lamp. The light and dark period was simulated using a timer based auto-cut off mechanism providing 16:8 hours of light: dark cycle. The temperature of the incubator was maintained and monitored at a constant $24^{\circ} \mathrm{C}$ using a thermostat coupled thermometer which pretty much is the average water temperature in the well mixed tropical estuaries.

The statistical analyses (Pearson's Correlation, Principal Correspondence Analysis, Regression, Standard Error, Standard Deviation, Mean etc.) for the entire period of the study depicted in the present thesis were performed with the use of Microsoft Excel 2007, Minitab 17 and XLSTAT 19 (statistical add-in of Excel) software packages. 
Table 1. Specifications of the Modified f/2 diatom artificial culture media specifications (GagneuxMoreaux et al., 2007).

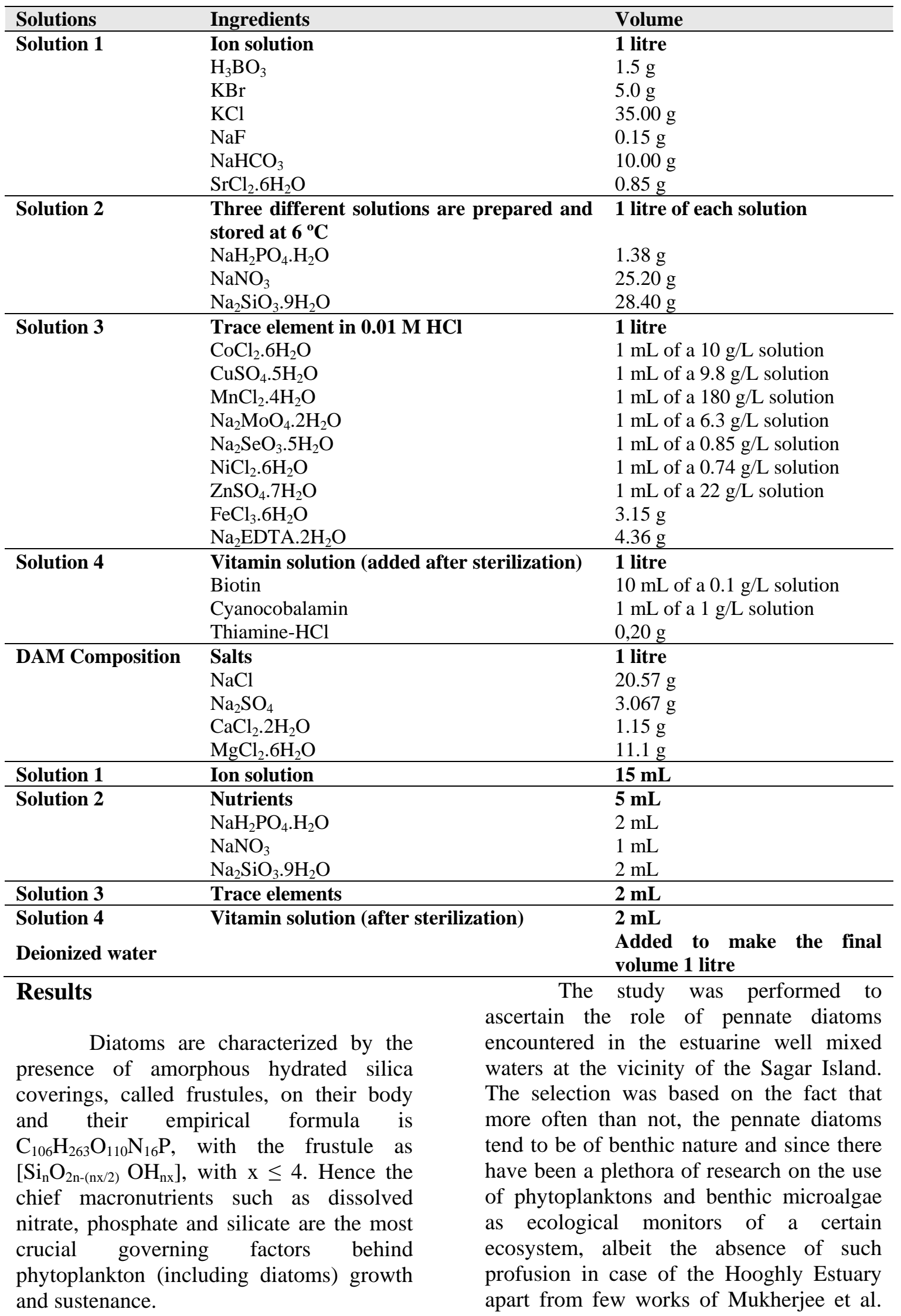


(2015a, b), it is always ecologically and economically viable to register new findings regarding the use of diatoms as bioindicators. The study is more significant as it is the first attempt to understand the roles pennate diatoms in the Sagar Island and surrounding regions as biomonitor of anthropogenic perturbations and if established, can certainly be added to the few findings from earlier research by Mukherjee et al. (2015a, b) in order to render the information holistic and helpful to any policy maker and future researchers.

The Table 2 represents the background meteorological and hydrological parameters of the sites of the sampling from which the inoculants were taken for the ex situ culture. The month for the collection for the purpose of the culture since this month is the spring bloom period and the probability of finding the most number of potential microalgal subjects is highest. A number of pennate diatoms were inoculated to the artificial culture media, Diatom Artificial Media or DAM, as well as in the respective sea water (filtered) samples to tally the responses of the inoculated species. This was attempted with the hypothesis that "any diatom able to reflect the changes in the stoichiometry of its surrounding precisely can be used as an ecologically accurate tool to monitor the health of the aquatic ecosystem which it is part of". Although the centric diatoms, in comparison, are better apt at doing so but the benthic sessile nature of many pennate diatom species render them quite precise in drawing inferences regarding eutrophication at a certain place. Only the three previously mentioned species demonstrated behavioural patterns consistent enough in both the selected culture media to be finally chosen as subject species for the intended experiment.

Table 2. Background meteorological as well as physicochemical and biological variables of the Hooghly Estuarine ecosystem at the sampling sites in February, 2016.

\begin{tabular}{|c|c|c|c|}
\hline Variables & $\begin{array}{l}\text { Kachuberia } \\
\text { (Mean } \pm \text { SE) }^{*}\end{array}$ & $\begin{array}{c}\text { Chemaguri } \\
\text { (Mean } \pm \text { SE) }\end{array}$ & $\begin{array}{c}\text { Gangasagar } \\
(\text { Mean } \pm \text { SE) }\end{array}$ \\
\hline Air Temperature $(\mathrm{aT})\left[{ }^{\circ} \mathrm{C}\right]$ & $26.3 \pm 0.3$ & $22.6 \pm 0.1$ & $25.1 \pm 0.7$ \\
\hline Water Temperature $(\mathrm{wT})\left[{ }^{\circ} \mathrm{C}\right]$ & $20.1 \pm 0.4$ & $23.8 \pm 0.1$ & $23.9 \pm 0.5$ \\
\hline Relative Humidity (Rh) [\%] & $41.9 \pm 0.4$ & $39.1 \pm 0.3$ & $39.5 \pm 0.8$ \\
\hline Wind speed $[\mathrm{m} / \mathrm{s}]$ & $1.5 \pm 0.07$ & $1.0 \pm 0.1$ & $2.2 \pm 0.9$ \\
\hline $\mathrm{pH}$ & $8.30 \pm 0.02$ & $8.05 \pm 0.01$ & $8.20 \pm 0.05$ \\
\hline Salinity (psu) & $20.2 \pm 0.7$ & $24.1 \pm 0.5$ & $28.2 \pm 0.1$ \\
\hline Dissolved Nitrate - Nitrogen $\left(\mathrm{NO}_{3}-\mathrm{N}\right)[\mu \mathrm{M}]$ & $3.01 \pm 0.08$ & $2.39 \pm 0.26$ & $2.23 \pm 0.37$ \\
\hline Dissolved Phosphate - Phosphorus $\left(\mathrm{PO}_{4}-\mathrm{P}\right)[\mu \mathrm{M}]$ & $0.69 \pm 0.01$ & $0.89 \pm 0.13$ & $1.09 \pm 0.06$ \\
\hline Dissolved Silicate - Silica $\left(\mathrm{SiO}_{4}-\mathrm{Si}\right)[\mu \mathrm{M}]$ & $70.41 \pm 3.77$ & $48.06 \pm 1.74$ & $35.72 \pm 0.99$ \\
\hline Dissolved Oxygen (D.O.) [mg/L] & $6.0 \pm 0.9$ & $5.6 \pm 0.3$ & $6.5 \pm 0.7$ \\
\hline Gross Primary Productivity (GPP) $\left[\mathrm{mgC} / \mathrm{m}^{3} / \mathrm{h}\right]$ & $78.12 \pm 5.21$ & $36.45 \pm 2.63$ & $101.56 \pm 12.17$ \\
\hline Net Primary Productivity (NPP) [mgC/m³/h] & $31.25 \pm 5.66$ & $26.04 \pm 2.98$ & $70.31 \pm 11.80$ \\
\hline Respiration (R) $\left[\mathrm{mgC} / \mathrm{m}^{3} / \mathrm{h}\right]$ & $56.25 \pm 8.72$ & $31.25 \pm 1.99$ & $31.5 \pm 3.65$ \\
\hline Chlorophyll $a(\mathrm{Chl} a)\left[\mathrm{mg} / \mathrm{m}^{3}\right]$ & $3.54 \pm 0.21$ & $4.56 \pm 0.82$ & $9.05 \pm 0.79$ \\
\hline Phytoplankton Population Density (Cell/L) & $0.158 \pm 0.001 \times 10^{6}$ & $0.122 \pm 0.002 \times 10^{6}$ & $0.166 \pm 0.001 \times 10^{6}$ \\
\hline
\end{tabular}

The experiment was performed in the laboratory maintained conditions because the monitoring of the three species exclusively in situ might yield observations that is biased since the other biotic components will also exert their individual as well as synergistic effect which will be sufficient to affect the behavioral responses of the three species and also due to the fact that the experimental was intended to be performed for only about four months comprising the late post-monsoon to the early pre-monsoon, which is not enough if any conclusion is needed to be drawn from the results obtained. 
Table 3. Species assemblages in the phytoplankton community encountered the three selected sites around the Gangasagar Island in the month of February, 2016.

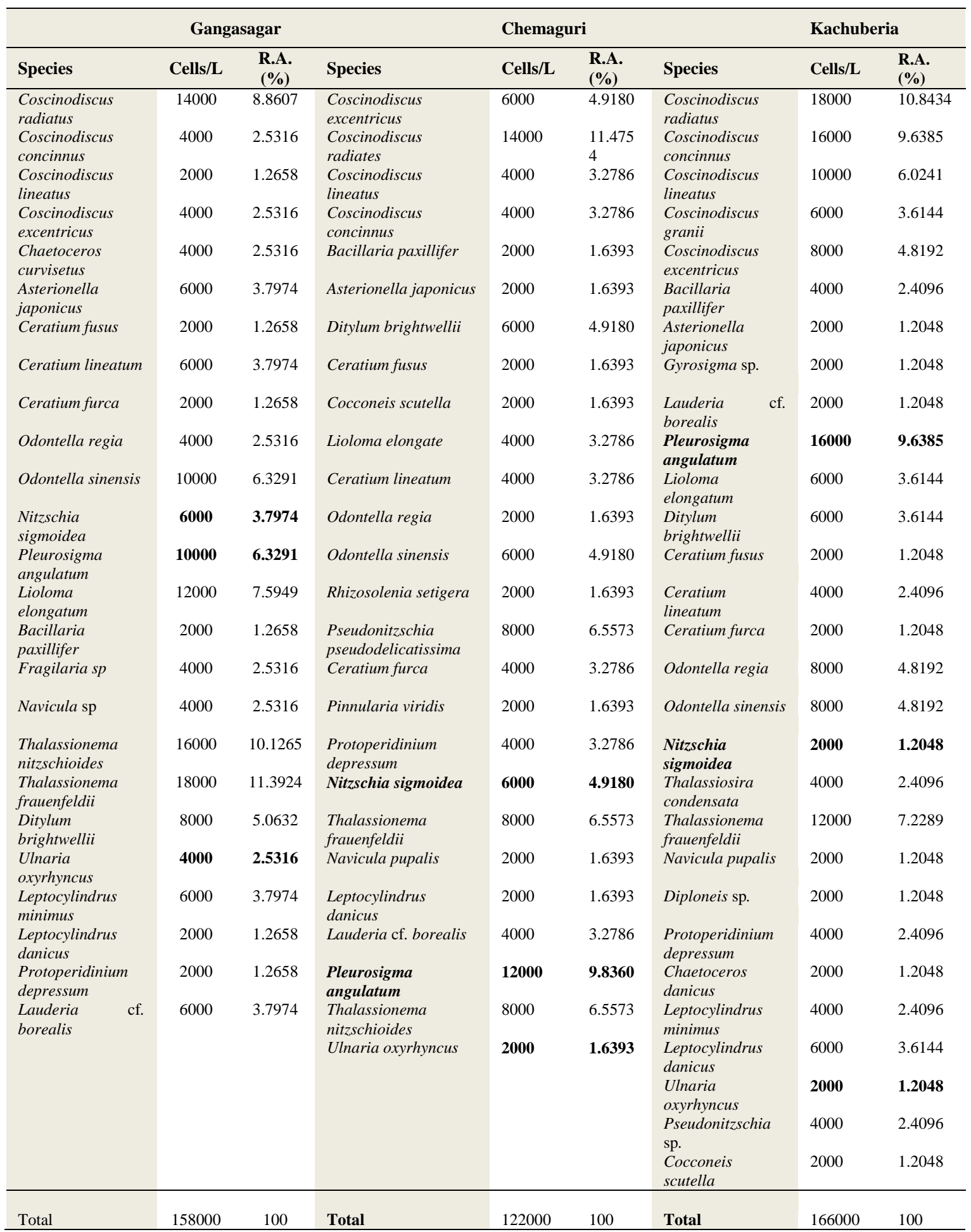

The Table 3 describes the species assemblage at the three collection sites of the Sagar Island in order to provide the data of the density at which the selected species were present in natural condition, and also to understand the contribution made by these species in the total estimated population of phytoplankton/microalgae. 
This also helps in a way to determine the species to be cultured based on the responses already exhibited by them in their natural admixture. Kachuberia and Gangasagar exhibited the highest population densities respectively, Chemaguri showed lower value.

The reason is the presence of tidal influences from every directions of Sagar Island and therefore has a greater chance of species admixing from both the freshwater and saline water of the Bay of Bengal. On the other hand, Chemaguri is a tidal creek with hush mangrove thickness and considerable anthropogenic activities and almost always is fed with and replenished by the higher saline high tide surge, hence harbouring mostly euryhaline and marine species.
The Figures 2-4 and the Table 4 depicts the culture specifications and the detailed inoculation regime followed during the experiment. From the table it is clearly evident that among the three pennate diatom species cultured, Pleurosigma angulatum was present in highest quantity and therefore can be presumed is be the most adaptive of them as well. And more important by their variation in their respective density was found to be consistent throughout the three sampling sites which automatically reflect that any observation made upon them should be reliable scientifically and should adhere to their behavioural pattern otherwise observed in nature.

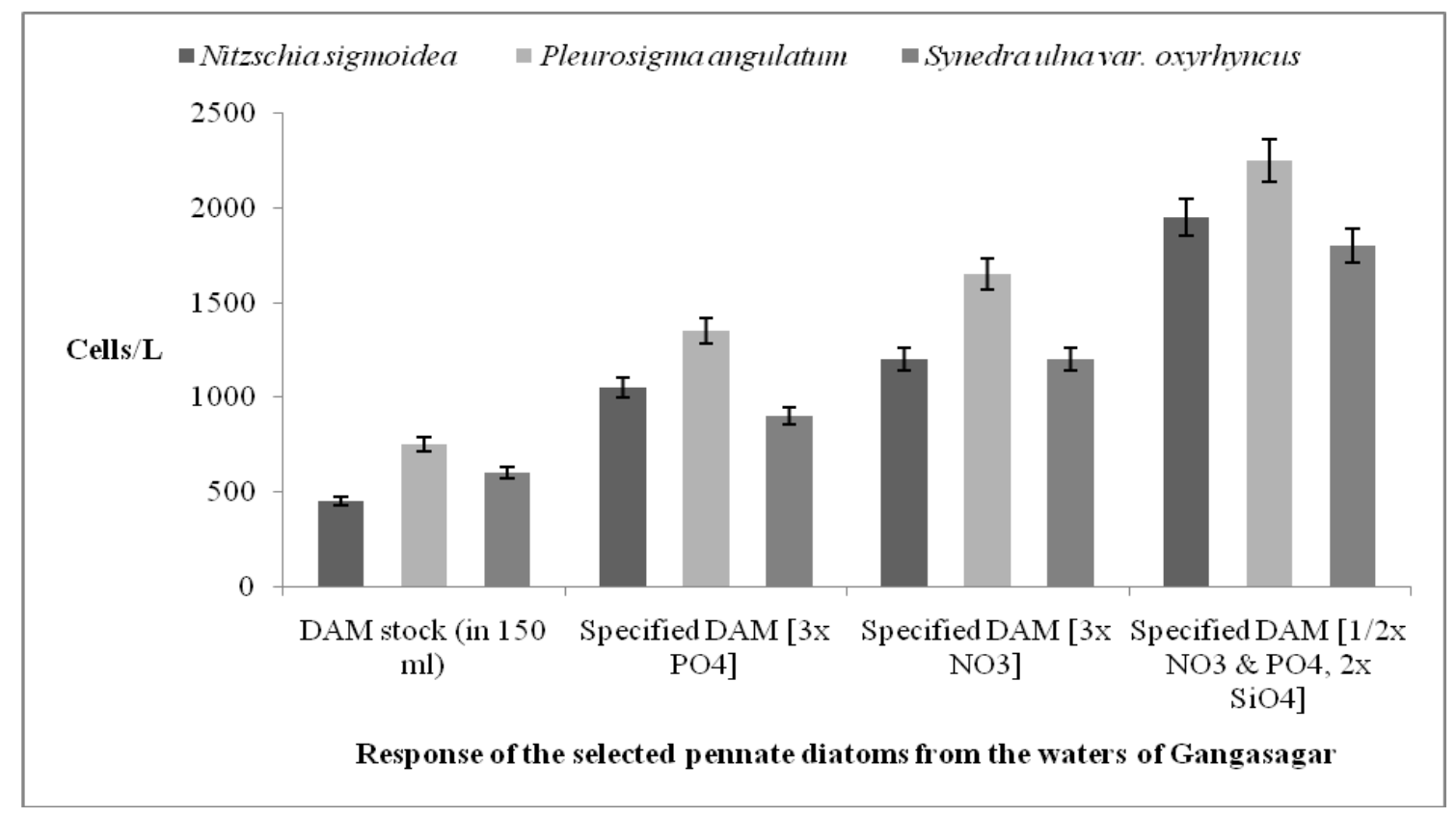

Figure 2. Showcasing the responses of the selected pennate diatom species to various artificial culture media specifications mentioned therein. The pennate diatoms species were collected from the Gangasagar, the Southernmost site of Sagar Is. in February, 2016. 


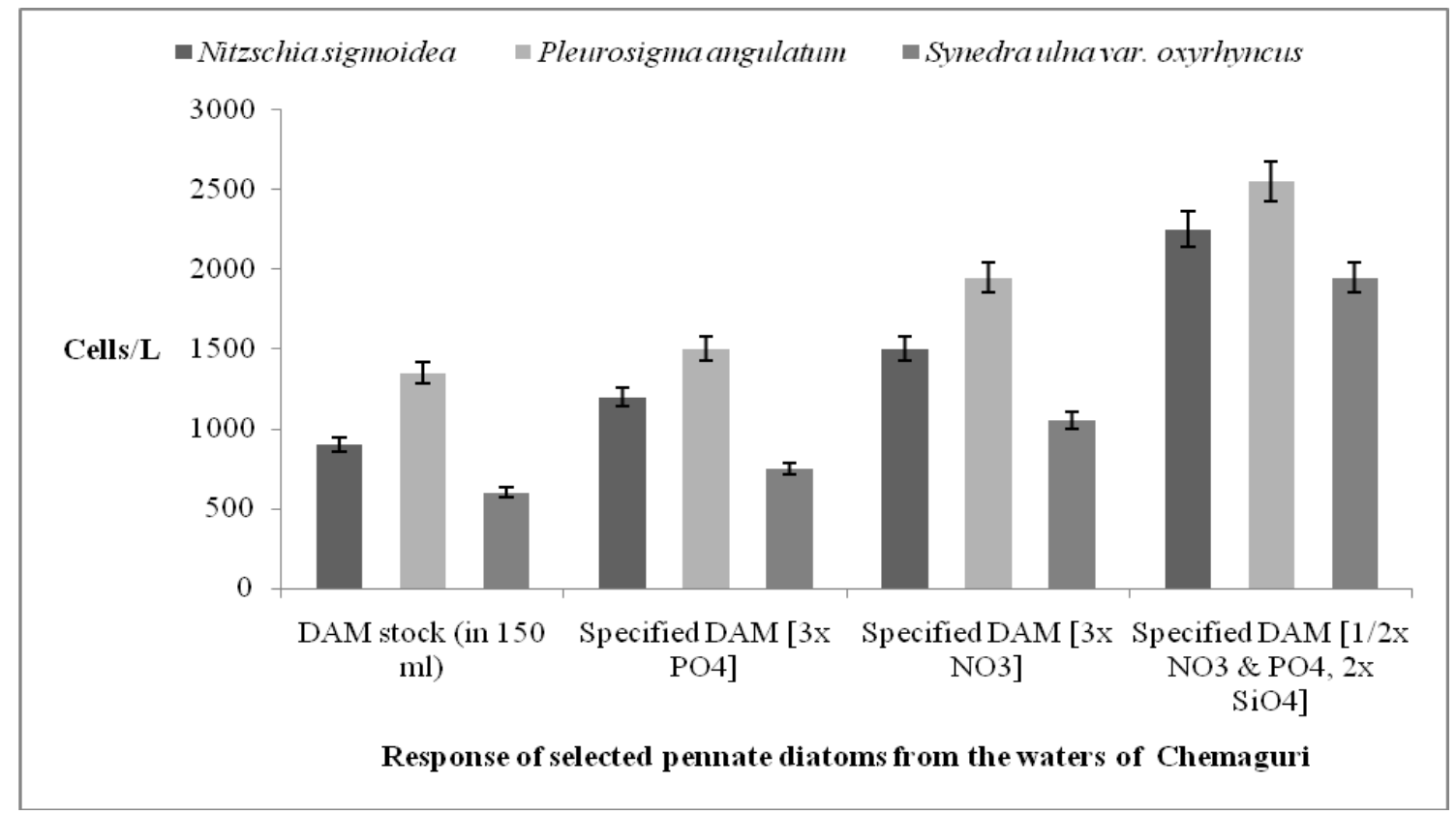

Figure 3. Showcasing the responses of the selected pennate diatom species to various artificial culture media specifications mentioned therein. The pennate diatoms species were collected from the Chemaguri, a mangrove forest flanked tide-dominated creek of Sagar Is. in February, 2016.

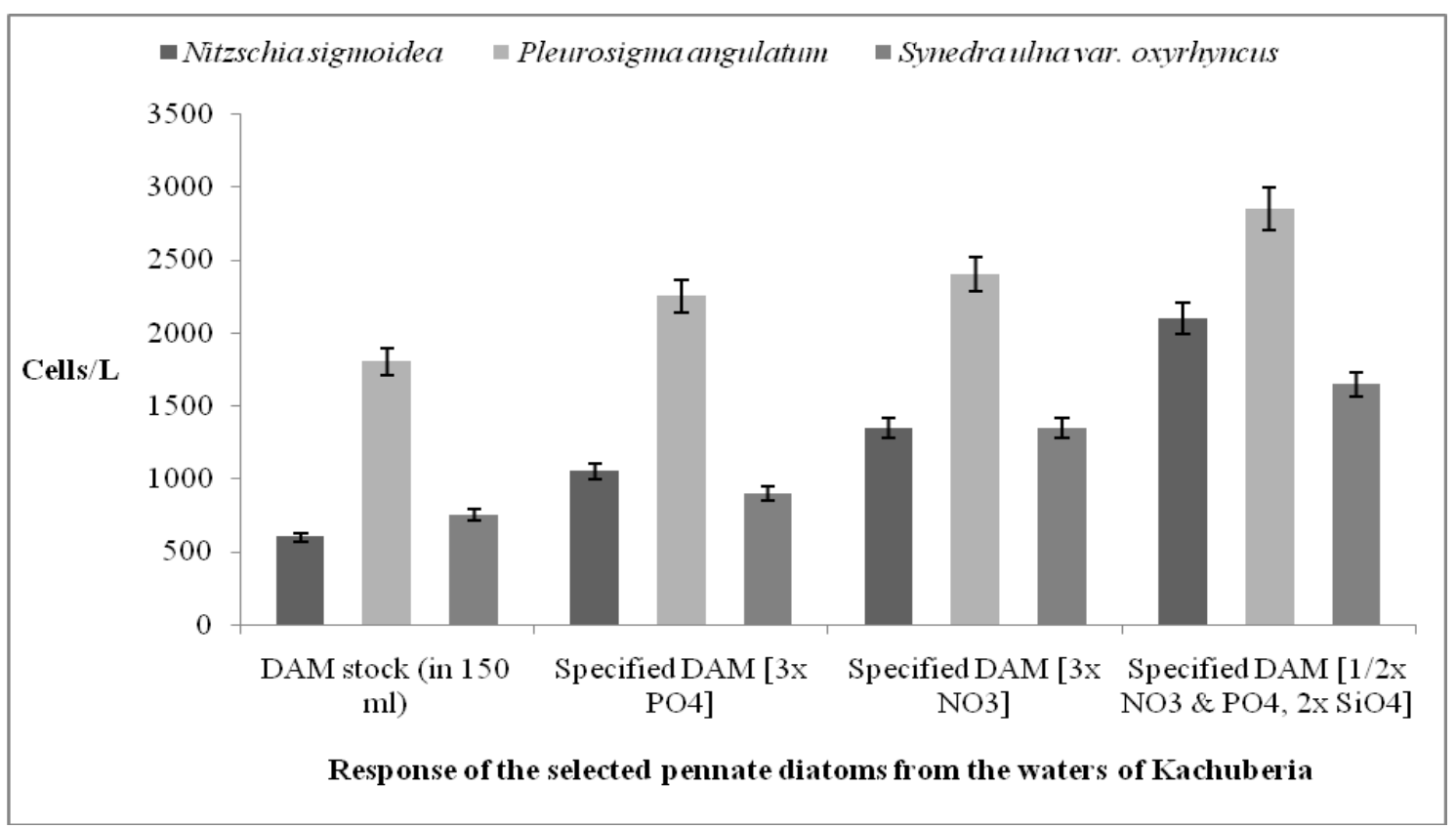

Figure 4. Showcasing the responses of the selected pennate diatom species to various artificial culture media specifications mentioned therein. The pennate diatoms species were collected from Kachuberia, the northernmost site of Sagar Is. in February, 2016, with very high anthropogenic activity.

The amount of inoculum administrated in each culture media specifications was $1 \mathrm{~mL}$ and each culture flask contained $150 \mathrm{~mL}$ of fluid. After the inocula were grown for an incubation period of 14 days, the resultant culture media revealed the density of the cultured species and it was found that even in laboratory situations, the density pattern was similar. 
Table 4. Changes in the number of cells of the selected pennate diatom species per unit volume various culture media specifications employed during the experiment to somewhat reflect the responsive behaviour observed in nature. (The values provided for the culture media are mean values provided with the standard errors).

\begin{tabular}{|c|c|c|c|c|c|c|c|}
\hline Stations & Species & $\begin{array}{l}\text { Seawater } \\
(\text { Cells/L) }\end{array}$ & $\begin{array}{c}\text { Within } \\
\text { inoculated } \\
\text { volume } \\
\text { (per } 1 \mathrm{~mL} \text { ) }\end{array}$ & $\begin{array}{c}\text { DAM stock } \\
\text { (per } 150 \mathrm{~mL} \text { ) }\end{array}$ & $\begin{array}{c}\text { Specified } \\
\text { DAM [3x } \\
\left.\mathrm{PO}_{4}\right]\end{array}$ & $\begin{array}{c}\text { Specified } \\
\text { DAM [3x } \\
\left.\mathrm{NO}_{3}\right]\end{array}$ & $\begin{array}{c}\text { Specified } \\
\text { DAM }[1 / 2 \\
x\left(\mathrm{NO}_{3}+\mathrm{PO}_{4}\right) \\
\left.\& 2 \mathrm{SiO}_{4}\right]\end{array}$ \\
\hline \multirow{3}{*}{ Gangasagar } & Nitzschia sigmoidea & 6000 & $5 \pm 1.23$ & $450 \pm 22.57$ & $1050 \pm 66.08$ & $1200 \pm 96.35$ & $1950 \pm 112.66$ \\
\hline & Pleurosigma angulatum & 10000 & $12 \pm .3 .66$ & $750 \pm 47.84$ & $1350 \pm 121.55$ & $1650 \pm 144.39$ & $2250 \pm 201.43$ \\
\hline & Ulnaria oxyrhyncus & 4000 & $5 \pm 0.67$ & $600 \pm 15.96$ & $900 \pm 32.22$ & $1200 \pm 46.34$ & $1800 \pm 161.25$ \\
\hline \multirow{3}{*}{ Kachuberia } & Nitzschia sigmoidea & 2000 & $4 \pm 0.33$ & $600 \pm 11.70$ & $1050 \pm 169.55$ & $1350 \pm 153.96$ & $2100 \pm 237.12$ \\
\hline & Pleurosigma angulatum & 16000 & $20 \pm 3.54$ & $1800 \pm 80.00$ & $2250 \pm 215.06$ & $2400 \pm 324.50$ & $2850 \pm 285.55$ \\
\hline & Ulnaria oxyrhyncus & 2000 & $6 \pm 1.05$ & $750 \pm 31.05$ & $900 \pm 78.92$ & $1350 \pm 112.45$ & $1650 \pm 106.74$ \\
\hline \multirow{3}{*}{ Chemaguri } & Nitzschia sigmoidea & 6000 & $10 \pm 2.67$ & $900 \pm 55.66$ & $1200 \pm 111.40$ & $1500 \pm 125.70$ & $2250 \pm 125.50$ \\
\hline & Pleurosigma angulatum & 12000 & $15 \pm 4.11$ & $1350 \pm 112.90$ & $1500 \pm 154.87$ & $1950 \pm 132.55$ & $2550 \pm 185.00$ \\
\hline & Ulnaria oxyrhyncus & 2000 & $4 \pm 0.22$ & $600 \pm 44.95$ & $750 \pm 53.99$ & $1050 \pm 48.50$ & $1950 \pm 202.35$ \\
\hline
\end{tabular}

The Figures 5-7 and Table 5 have revealed the actual effect of the culture media specifications upon the three species grown in them. Media specification comprising halved $\mathrm{NO}_{3}$ and $\mathrm{PO}_{4}$ and twice the amount $\mathrm{SiO}_{4}$ present normally in the DAM garnered the highest growth in numbers among all the three species followed by increased nitrates and phosphates. And the pattern was similar in the species isolated from all the three collection sites indicating some sort of reservation in expressivity under similar nutrient influences irrespective of the conditions present in their natural habitat.

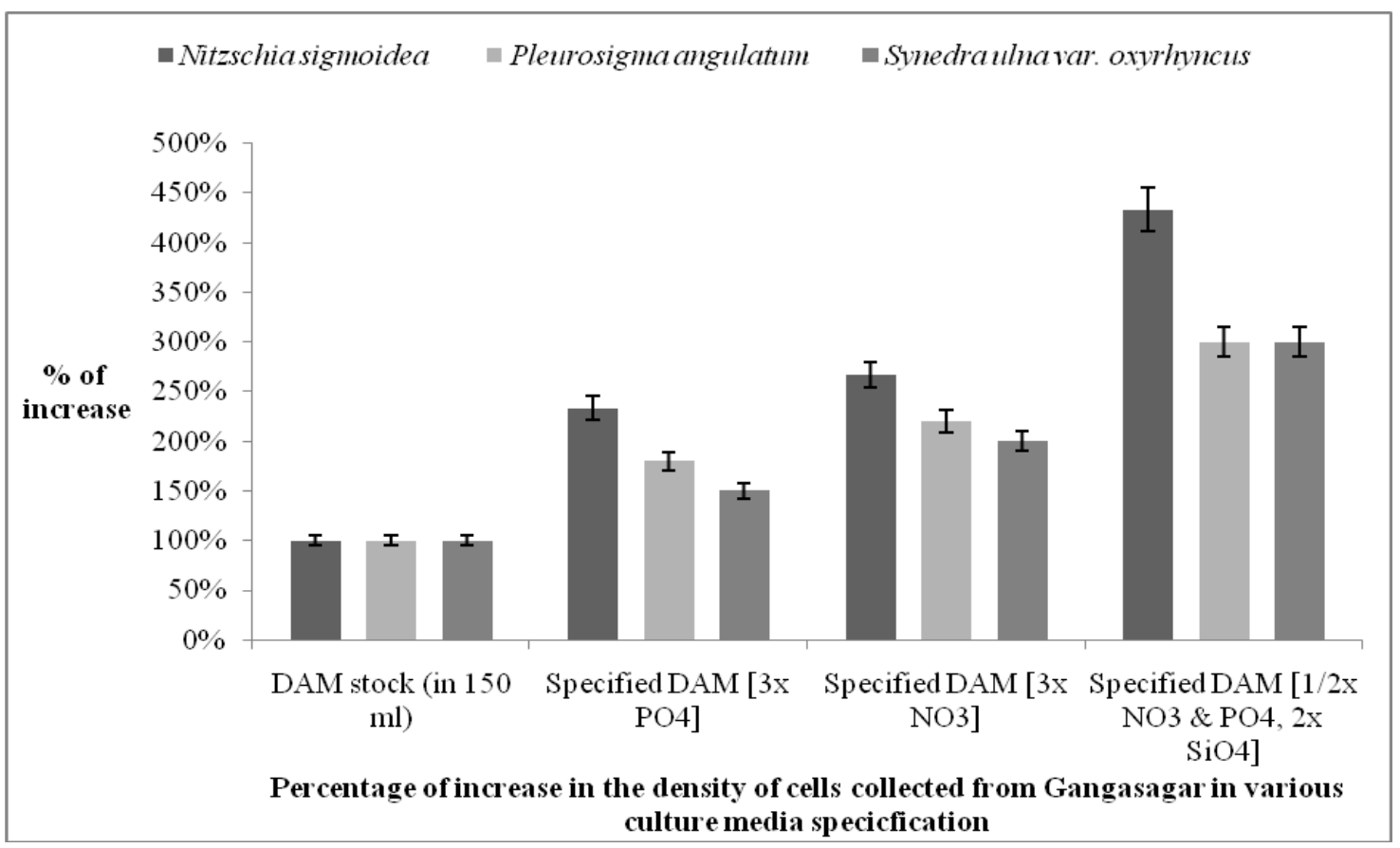

Figure 5. Percentage of increase in the species density of the selected pennate diatoms collected from Gangasagar over the control culture, in artificial laboratory condition. 


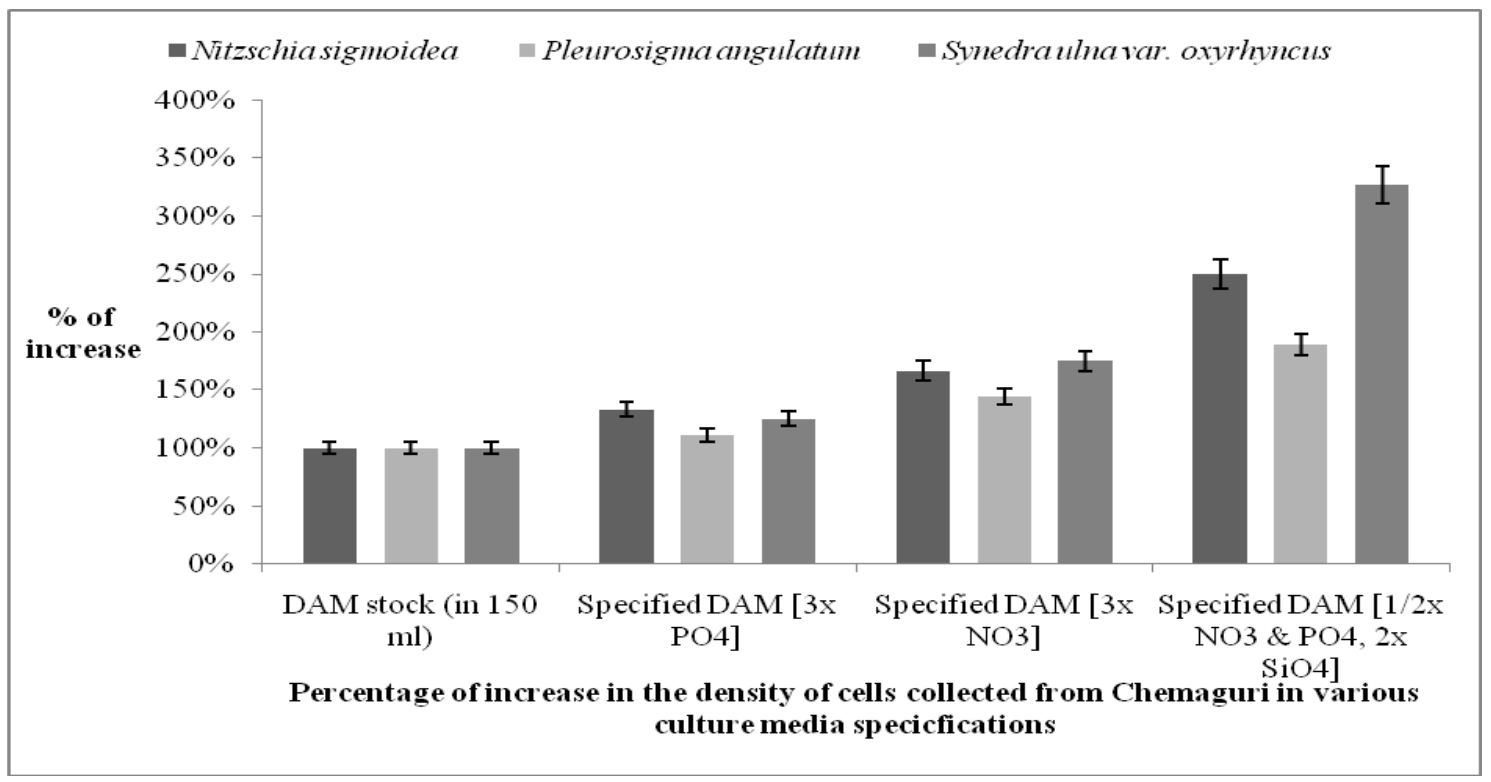

Figure 6. Percentage of increase in the species density of the selected pennate diatoms collected from Chemaguri over the control culture, in artificial laboratory condition.

In spite of the fact that Pleurosigma angulatum registered the highest values per litre of the sea water among the three species chosen and also in the inocula, it was Nitzschia sigmoidea which responded most vigorously and spontaneously, this points to the fact that when it comes to adaptive capability among the selected species, Nitzschia sigmoidea can exhibit greater flexibility in exploiting the available resources which somehow is not fully expressed in nature due to interspecies competition or some other intrinsic or extrinsic factors influencing the species.

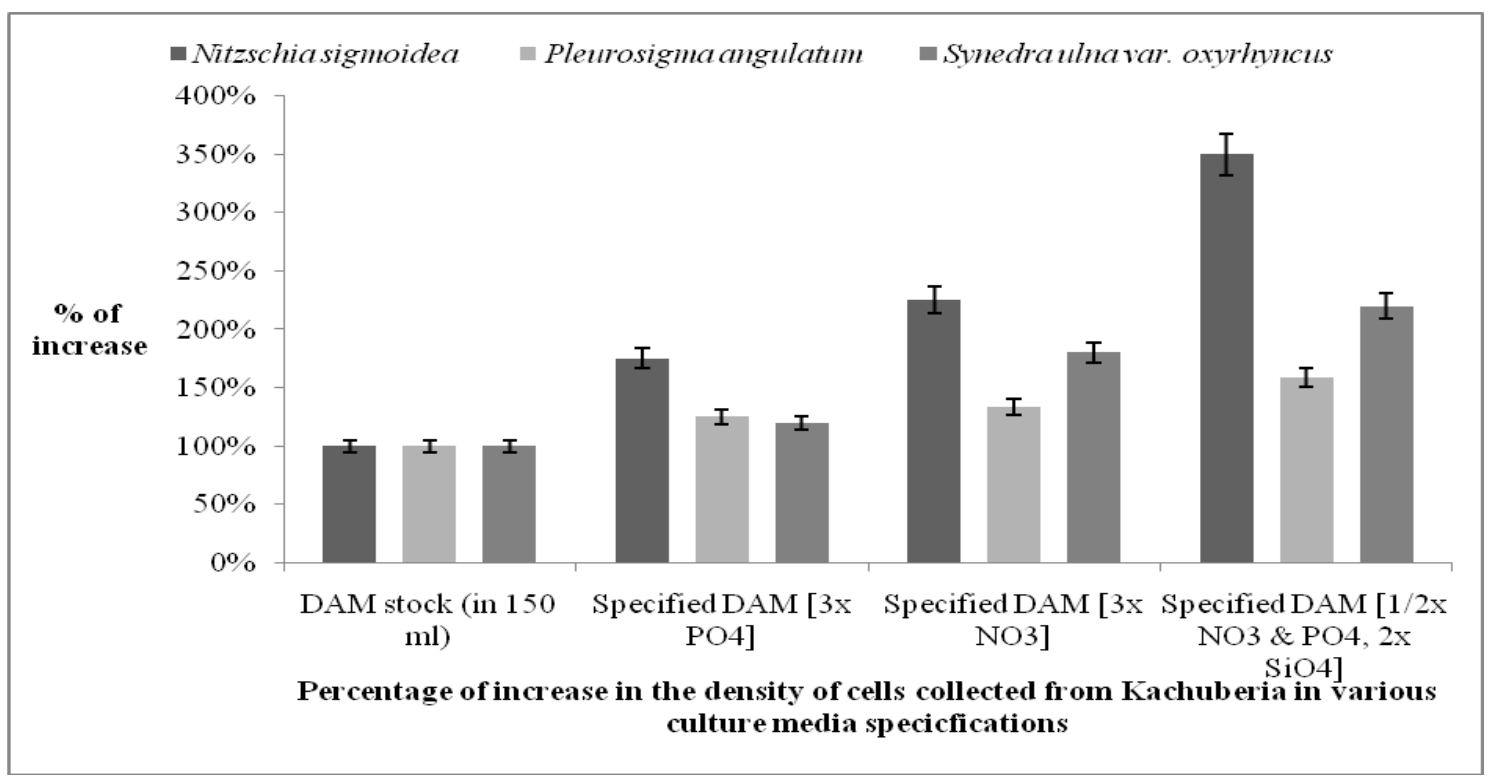

Figure 7. Percentage of increase in the species density of the selected pennate diatoms collected from Kachuberia over the control culture, in artificial laboratory condition. 
Table 5. Percentage of increase in the density of cells among the selected pennate diatoms species collected from the different collection sites within the employed culture media variations.

\begin{tabular}{|c|c|c|c|c|c|}
\hline $\begin{array}{l}\text { Sampling } \\
\text { Stations }\end{array}$ & Cells/L & $\begin{array}{l}\text { DAM stock } \\
\text { (in } 150 \mathrm{~mL} \text { ) }\end{array}$ & $\begin{array}{c}\text { Specified } \\
\text { DAM }\left[3 \times \mathrm{PO}_{4}\right]\end{array}$ & $\begin{array}{c}\text { Specified } \\
\text { DAM }\left[3 x \mathrm{NO}_{3}\right]\end{array}$ & $\begin{array}{c}\text { Specified DAM [1/2x }\left(\mathrm{NO}_{3}+\right. \\
\left.\left.\mathrm{PO}_{4}\right) \& 2 \mathrm{x} \mathrm{SiO}\right]\end{array}$ \\
\hline \multirow{3}{*}{ Gangasagar } & Nitzschia sigmoidea & $100 \%$ & $233.33 \%$ & $266.67 \%$ & $433.33 \%$ \\
\hline & Pleurosigma angulatum & $100 \%$ & $180.00 \%$ & $220.00 \%$ & $300.00 \%$ \\
\hline & Ulnaria oxyrhyncus & $100 \%$ & $150.00 \%$ & $200.00 \%$ & $300.00 \%$ \\
\hline \multirow{3}{*}{ Chemaguri } & Nitzschia sigmoidea & $100 \%$ & $133.33 \%$ & $166.67 \%$ & $250.00 \%$ \\
\hline & Pleurosigma angulatum & $100 \%$ & $111.11 \%$ & $144.44 \%$ & $188.89 \%$ \\
\hline & Ulnaria oxyrhyncus & $100 \%$ & $125.00 \%$ & $175.00 \%$ & $326.67 \%$ \\
\hline \multirow{3}{*}{ Kachuberia } & Nitzschia sigmoidea & $100 \%$ & $175.00 \%$ & $225.00 \%$ & $350.00 \%$ \\
\hline & Pleurosigma angulatum & $100 \%$ & $125.00 \%$ & $133.33 \%$ & $158.33 \%$ \\
\hline & Ulnaria oxyrhyncus & $100 \%$ & $120.00 \%$ & $180.00 \%$ & $220.00 \%$ \\
\hline
\end{tabular}

However, the three species with their ability to cope with various nutrient profile as well as artificial simulation of their natural habitat all point towards their innate ability to response to any changes in their immediate ambient environment and this is the most crucial aspect of a species of microalgae to be chosen as biomonitor of a certain aquatic ecosystem, especially one such as the highly dynamic and well mixed Hooghly Estuary. The Table 6, through the significant correlation values among the culture media specificity and cell density of the selected cultured species from the three sampling sites fully indicates the result observed in Table 5 and once again highlights the potential applicability of the three pennate diatoms as biomonitor of the nutrient profile disturbed by intense anthropogenic activities in and around a well mixed estuarine ecosystem, such as the Hooghly Estuary.

Table 6. The correlation values between the responses of the selected cultured species collected from various stations to the specifications of the culture media employed.

\begin{tabular}{|c|c|c|c|}
\hline Sampling stations & $\begin{array}{l}\text { DAM: Specified DAM } \\
{\left[3 \times \mathrm{NO}_{3}\right]}\end{array}$ & $\begin{array}{c}\text { DAM: Specified DAM } \\
{\left[3 \times \mathrm{PO}_{4}\right]} \\
\end{array}$ & $\begin{array}{c}\text { DAM: Specified DAM } \\
{\left[1 / 2 \times\left(\mathrm{NO}_{3}+\mathrm{PO}_{4}\right) \& 2 \times \mathrm{SiO}_{4}\right]}\end{array}$ \\
\hline Kachuberia & +0.9934 & +0.9766 & +0.8799 \\
\hline
\end{tabular}

\section{Discussion}

The experiment was performed to establish, to some extent, the candidature of a few selected pennate diatom species viz. Nitzschia sigmoidea, Pleurosigma angulatum and Ulnaria oxyrhyncus by recording and interpreting their behavioural responses in various ex situ culture environments.

Periphytic diatoms have been used as monitors of aquatic ecosystems, by following two basic approaches (Poulíčková et al., 2004) that involve either the development of autecological indices (Kolkwitz and Marsson, 1908) to indicate levels of pollution from assemblages of tolerant species (Zelinka and Marvan, 1961; Lange-Bertalot, 1979) or by monitoring primarily the diatom diversity as a general indicator of river 'health' (Patrick and Strawbridge, 1963).

From the Table 2, it can be observed that there were many pennate diatom species in the natural seawater (estuarine) of the selected study and sampling sites of the Hooghly estuary circumfering the Sagar Island. The diatoms, after collection, were isolated manually and specifically the pennate diatoms were inoculated in the artificial $f / 2$ culture media, known as Diatom Artificial Media or DAM. This media is the modification of the Provasoli-Guillard media developed by the centre for culture of marine species. The intention was to delineate those species which responded to the sudden change relatively better than others so that those 
few can be worked with in the experiments in future. Among them the three prementioned subject species showed prominence and some others were far more fastidious in laboratory culture to grow despite of the fact that some amongst them, e.g. Bacillaria sp, Fragilaria sp etc. form frequent blooms in natural conditions (unmanipulated or unperturbed environments) and act as dominant fraction of a certain aquatic ecosystem. The three species chosen contributed to their population densities in the following manner: Nitzschia sigmoidea (1.20484.9180\%), Pleurosigma angulatum (6.3291-9.8360\%) and Ulnaria oxyrhyncus (1.2048-2.5316\%).

This fact has been beautifully captured in the figures 2-4, where Pleurosigma angulatum continued to express itself over the other two in eventual density of the species in every combination of the employed culture media. And this trend held true for all the individuals belonging to the three species that were sampled from three different sampling sites. The values in case of the other two pennate diatom species generally exhibited patterns similar all over with minor deviations in various culture media. The maximum possible growth in numbers took place in the culture media containing double silicates. This is an obvious fact, once again proven, that all diatoms require silicates to develop their frustules and therefore increased dissolved silicate concentrations would almost always invoke growth spikes in diatoms in nature as well as in any culture media.

From Figures 2-4, it can be summarized that in the marine and also in the estuarine ecosystems, dissolved nitrates act as the most important chemical parameter, it can also be highlighted that among the most important dissolved plant nutrients, nitrates edged past phosphate in terms of the response to their increased amount in the culture media variations. Although phosphate and nitrates both are quintessential in growth and sustenance of any organisms of which diatoms are no exceptions, the data generated from the experiment vindicated with the notion of nitrate being limiting factor in marine organisms.

Use of biological organisms as indices depend upon the species assemblage in which the intended monitor is present or absent at a certain phase of their life cycle or period of the sampling session, or they are unaffected by the changes in their surroundings, which is not the characteristic features generally considered prior to assigning a bioindicator organisms/ species. There are certain demerits to this otherwise precise method of ecological assessment in that the assemblages of certain species or "substitutions of species in many communities in common as a result of random effects or natural fluctuations of the species" according to Daufresne et al. (2009). Hence, it is unwise and rash to draw an inference regarding the present experiment from a single set of data about the dominance of certain species over its counterparts under similar situations and probable demarcation as a biomonitor from it. This sort of data point to the fitness of the subject species to tolerate varied conditions in the laboratory but the responses generated by such species might easily be masked or thwarted due to the manifestation of other organisms or other diatom specifics which failed to grow in culture conditions but are more adapt at sensing slightest of changes is their respective ambience and are therefore far better suited to be used as ecological monitors. In that light, the Table 4, 5 and Figures 5-7 are very significant from the preciseness of the selected pennate diatom species. These tables and figures point towards the expressivity of the diatoms and not merely the numerical supremacy of these species.

It is clearly evident from the Table 4 that the species were not inoculated in equal numbers per unit volume. This was because of the fact that due to the greater numbers of Pleurosigma angulatum is the selected sampling sites and its number per $1 \mathrm{~mL}$ of water was higher than both Nitzschia sigmoidea and Ulnaria oxyrhyncus. Although this might be the reason behind the far greater number of Pleurosigma angulatum in the culture 
media and it is all too easy to associate the species of Pleurosigma with the moniker "bioindicator", but in order to fully glimpse the scenario, one has to scrutinize the Table 5 which is exclusively pointing out to the expressivity of the three species under investigation in terms of percentage of increase in number from the inoculation to the mature culture, after a period of 14 days, in all the culture media specificities.

Here for the first time all the three species have been observed to respond equally under the artificial culture media. More interestingly, the dominance pattern has yielded something new since every other analytical account revealed the ascendancy of Pleurosigma angulatum among the three diatom species cultured. But, when the percentage of growth conversion was considered Pleurosigma angulatum only appeared to be at par with Ulnaria oxyrhyncus and the new leader of the pack was Nitzschia sigmoidea. In spite of the fact that at the time of inoculation, Nitzschia sigmoidea was 2/5th times lower in number per unit volume of inoculum and still due to the superior adaptability and tolerance to a wider range of environmental parametric constraints and also due to the absent of certain impeding factors which held complete proliferation of this species at bay, it managed to produce more individuals in equal time and similar culture conditions compared to its apparently more dominant diatom species and also than Ulnaria oxyrhyncus.

The beauty of this phenomenon lies in the fact that the pattern was reserved for the samples collected from all the three sampling stations which not only points to the variation in the hydrological parameters of the species collected but also underlines the fact that Nitzschia sigmoidea behaved in a similar manner irrespective of the station which it was collected from and that is must have some innate ability to cope with the changes in its ambient surroundings through exploiting the available conditions better than many presumed dominant species once certain constraints are removed or are absent from its ecosystem. These factors are yet to be clearly delineated but it is sufficient to note that these species have the ability to serve as monitors of nay changes, brought about naturally or anthropogenically, to their ecosystem through their tolerance or sensitivity. The Table 6 has once again bolstered the fact that in the marine or marine dominated estuarine ecosystem, such as the one the experiment was based upon, species of nitrogen, especially dissolved nitrate-nitrogen serves as the most important limiting nutrient for phytoplanktons. It is clearly observable from the table that although spiked silicate in the basic culture media extricated the stress of the cultured species in terms of their numbers per unit volume, on average in all the three stations the species responded more in media containing increased $\mathrm{NO}_{3}$ than in any other combinations used. This is a significant information and glimpses in the intricate complexities in the life of diatoms and how some of them can be successfully appointed as biological indicators which will not only be precise but both ecologically and economically feasible as well.

\section{Conclusion}

The objectives of the study were to delineate some key diatom (pennate) species with potentials to serve as bioindicators of estuarine ecosystems and also to compare the growth rate of such species on various synthetic culture media with equally assorted ingredients (macro and micro nutrients, trace metals, vitamins etc.) to get a better idea on the sensitivity of those species to the precise concentrations of certain nutrients (since every culture media has their unique stoichiometry). Among the various diatom species studied, Pleurosigma angulatum, Nitzschia sigmoidea and Ulnaria oxyrhyncus were found to behave most significant and satisfactory for our work.

The study is more significant as it is the first attempt to understand the roles pennate diatoms in the Sagar Island and surrounding regions as biomonitor of anthropogenic perturbations and if established, can certainly be added to the few findings from earlier research by 
Mukherjee et al. (2015a, b) in order to render the information holistic and helpful to any policy maker and future researchers. The three species with their ability to cope with various nutrient profile as well as artificial simulation of their natural habitat all point towards their innate ability to response to any changes in their immediate ambient environment and this is the most crucial aspect of a species of microalgae to be chosen as biomonitor of a certain aquatic ecosystem and Media specification comprising halved $\mathrm{NO}_{3}$ and $\mathrm{PO}_{4}$ and twice the amount $\mathrm{SiO}_{4}$ present normally in the DAM garnered the highest growth in numbers among all the three species.

The work represented the approach and effort behind the establishment of bioindicators of Hooghly Estuary in order to properly monitor the globally significant ecosystem at an economically viable and ecologically amicable way. The results showed some promising glimpses on the use of pennate diatoms as monitoring tools of any aquatic ecosystem and those species which couldn't have been cultured successfully might hide better candidates as biomonitors and further works of this kind is quintessential in bringing them to light which will not only benefit researchers but the societies that solely depend on the coastal aquatic ecosystems for their livelihood.

\section{Conflicts of interest}

Authors declare that they have no conflict of interests.

\section{Reference}

Al-Kandari, M.; Al-Yamani, F. Y.; Al-Rifaie, K. Marine Phytoplankton Atlas of Kuwait's Waters. Kuwait: Kuwait Institute for Scientific Research, 2009.

Daufresne, M.; Lengfellner, K.; Sommer, U. Global warming benefits the small in aquatic ecosystems. Proc. Natl. Acad. Sci. USA, v. 106, p. 12788-12793, 2009. http://dx.doi.org/10.1073/pnas.0902080106

Desikachary, T. V. Atlas of diatoms. Madras: Madras Science Foundation, 1986-1989. (v. 1-6, 809 plates).
DiTullilo, G. R.; Hutchins, D. A.; Bruland, $\mathrm{K}$. W. Interaction of iron and major nutrients controls phytoplankton growth and species composition in the tropical North Pacific Ocean. Limnol. Oceanogr., v. 38, no. 3, p. 495-508, 1993. http://dx.doi.org/10.4319/lo.1993.38.3.0495

Dugdale, R. C.; Goering, J. J. Uptake of new and regenerated forms of nitrogen in primary productivity. Limnol. Oceanogr., v. 12, p. 196-206, 1967. http://dx.doi.org/10.4319/ lo.1967.12.2.0196

Dugdale, R. C.; Wilkerson, F. P.; Barber, R. T.; Chavez, F. P. Estimating new production in the equatorial Pacific Ocean at $150^{\circ}$ W. J. Geophys Res., v. 97, no. C1, p. 681-686, 1992. http://dx.doi.org/10.1029/91JC01533

Gagneux-Moreaux, S.; Moreau, C.; Gonzalez, J. L.; Cosson, R. P. Diatom artificial medium (DAM): a new artificial medium for the diatom Haslea ostrearia and other marine microalgae. J. Phycol., v. 19, no. 5, p. 549-556, 2007. http://dx.doi.org/10.1007/s10811-007-9169-4

Grasshoff, K.; Ehrhardt, M.; Kremling, K. Methods of seawater analysis. In: Grasshoff, K.; Ehrhardt, M.; Kremling, K. (Eds). Das Verlagsprogramm umfasst die Bereiche Chemie GmbH, 1983.

Graziano, L. M.; La Roche, J.; Geider, R. J. Physiological response to phosphorus limitation in batch and steady-state cultures of Dunaliella tertiolecta (Chlorophyta): a unique stress protein as an indicator of phosphate deficiency. J. Phycol., v. 32, no. 5, p. 825-838, 1996. http://dx.doi.org/10.1111/j.0022-3646.1996. 00825.x

Hasle, G. R.; Syvertsen, E. R. Marine diatoms. In: Tomas, C. R. (Ed.). Identifying marine phytoplankton. London: Academic Press, 1997. p. 5-385.

Hecky, R. E.; Kilham, P. Nutrient limitation of phytoplankton in freshwater and marine environments: a review of recent evidence on the effects of enrichment. Limnol. Oceanogr., v. 33, no. 4, pt. 2, p. 796-822, 1988. http://dx.doi.org/10.4319/lo.1988.33.4part2.0796

Hotzel, G.; Croome, R. A. Phytoplankton methods manual for Australian freshwaters. Australia: Land and Water Resources Research and Development Corporation, 1999.

Kolkwitz, R.; Marsson, M. Ecology of plant saprobia. In: Keup, L. E.; Ingram, W. M.; Mackenthun, K. M. (Eds.). Biology of water pollution. Washington: Federal Water Pollution Control Administration, 1908. p. 47-52.

Lange-Bertalot, H. Pollution tolerance of diatoms as a criterion for water quality 
estimation. Beih. Nova Hedwigia, v. 64, no. 1, p. 285-304, 1979.

Martin, J. H. ; Coale, K. H.; Johnson, K. S.; Fitzwater, S. E.; Gordon, R. M.; Tanner, S. J.; Hunter, C. N.; Elrod, V. A.; Nowicki, J. L.; Coley, T. L.; Barber, R. T.; Lindley, S.; Watson, A. J.; Van Scoy, K.; Law, C. S.; Liddicoat, M. I.; Ling, R.; Stanton, T.; Stockel, J.; Collins, C.; Anderson, A.; Bidigare, R.; Ondrusek, M.; Latasa, M.; Millero, F. J.; Lee, K.; Yao, W.; Zhang, J. Z.; Friederich, G.; Sakamoto, C.; Chavez, F.; Buck, K.; Kolber, Z.; Greene, R.; Falkowski, P.; Chishol, S. W.; Hoge, F.; Swift, R.; Yungel, J.; Turner, S.; Nightingale, P.; Hatton, A.; Liss, P.; Tindale, N. W. Testing the iron hypothesis in ecosystems of the Equatorial Pacific Ocean. Nature, v. 371, p. 123-129, 1994. http://dx.doi.org/10.1038/371123a0

Morel, F. M. M. Kinetics of nutrient uptake and growth in phytoplankton. J. Phycol., v. 23, p. 137-150, 1987. http://dx.doi.org/10.1111/ j.1529-8817.1987.tb04436.x

Mukherjee, A.; De, M.; Maiti, T. K.; De, T. K. Use of dominant centric diatoms of well mixed tropical estuaries as indicators to nutrient rich environments. Int. J. Adv. Lif. Sci., v. 7, no. 2, p. 329-337, 2014. Available from: $<$ http://www.unitedlifejournals.com/ijals/viewpdf.php?id=201>. Accessed in: Mar. 16, 2016.

Mukherjee, A.; Das, S.; Chakraborty, S.; De, T. K. Laboratory experiment reveals some key factors behind auxospore induction in two ubiquitous centric diatoms of Hooghly Estuary, Bay of Bengal, India. Int. J. Pure App. Biosci., v. 3, no. 3, p. 94-104, 2015. Available from: $<$ http://www.ijpab.com/form/2015 Volume 3, issue 3/IJPAB-2015-3-3-94-104.pdf>. Accessed on: Mar. 16, 2016.

Mukherjee, A.; Das, S.; Chakraborty, S.; De, T. K. Study on mangrove associated estuarine waters of Northeastern Bay of Bengal reveals potential diatom indicators of dissolved inorganic compounds. Braz. J. Biol. Sci., v. 2, n. 3, p. 155-168, 2015. http://dx.doi.org/ 10.21472/bjbs.020316

Mukhopadhyay, S. K.; Biswas, H.; De, T. K.; Jana, T. K. Fluxes of nutrients from the tropical River Hoogly at the land-ocean boundary of Sundarban, NE coast of Bay of Bengal, India. J. Mar. Syst., v. 62, no. 1/2, p 9-21, 2006. http://dx.doi.org/10.1016/j.jmarsys.2006.03.004
Patrick, R.; Strawbridge, D. Variation in the structure of natural diatom communities. Am. Nat., v. 97, p. 51-57, 1963. Available from: $<$ http://www.jstor.org/stable/2458369>.

Accessed in: Mar. 16, 2016.

Poulíčková, A.; Duchoslav, M.; Dokulil, M. Littoral diatom assemblages as indicators of lake trophic status: a case study from perialpine lakes in Austria. Eur. J. Phycol., v. 39, p. 143152, 2004. http://dx.doi.org/10.1080/09670260 42000201876

Price, N. M.; Ahner, B. A.; Morel, F. M. M. The Equatorial Pacific Ocean: grazer-controlled phytoplankton populations in an iron-limited ecosystem. Limnol. Oceanogr., v. 39, no. 3, p. 520-539, 1994. http://dx.doi.org/10.4319/ lo.1994.39.3.0520

Redfield, A. C.; Ketchum, B. H.; Richards, F. A. The influence of organisms on the composition of seawater. In: Hill, M. N. (Ed.). The composition of seawater: comparative and descriptive oceanography. The sea: ideas and observations on progress in the study of the seas. 2. ed. New York: Wiley Interscience, 1963. p. 26-77.

Smith, S. V.; Atkinson, M. J. Phosphorus limitation of net production in a confined aquatic ecosystem. Nature, v. 307, p. 626-627, 1984. http://dx.doi.org/10.1038/307626a0

Strickland, J. D. H.; Parsons, T. R. A practical handbook of seawater analysis. Fish Res. Board Canada, 1968.

Sun, J.; Liu, D. Geometric models for calculating cell biovolume and surface area for phytoplankton. J. Plankton Res., v. 25, no. 11, p. 1331-1346, 2003. http://dx.doi.org/10.1093/ plankt/fbg096

Timmermans, K. R. Growth rates of large and small Southern Ocean diatoms in relation to availability of iron in natural seawater. Limnol. Oceanogr., $\quad$ v. 46, p. 260-266, 2001. http://dx.doi.org/10.4319/lo.2001.46.2.0260

UNESCO. Convention Concerning the Protection of the World Cultural and Natural Heritage. Paris: UNESCO, 1999. Available from: <http://whc.unesco.org/ archive/1999/whc-99-conf204-15e.pdf >.

Accessed on: Mar. 16, 2016.

Zelinka, M.; Marvan, P. Zur Präzisierung der biologischen Klassifikation des Rheinheit fliessender Gewässer. Arch. Hydrobiol., v. 57, p. 389-407, 1961.

License information: This is an open-access article distributed under the terms of the Creative Commons Attribution License, which permits unrestricted use, distribution, and reproduction in any medium, provided the original work is properly cited. 